\title{
MEKANISME PENGELOLAAN DANA TABARRU' ASURANSI SYARIAH PRUDENTIAL LIFE ASSURANCE
}

\author{
Muhammad Kambali \\ STAI Al-Azhar Menganti Gresik \\ e-mail: hambali236@gmail.com
}

\begin{abstract}
Sharia Insurance according to a binding ruling in religious matters (fatwa) of the National Shari'ah Board of the Indonesian Ulama Council no: 21 IDSN-MUI/ X / 2001 is a mutual effort to help among a number of people/parties through investment in assets or tabarru' which provides a pattern of return to face certain risks through engagement in accordance with the sharia. PRUlink sharia is an insurance product associated with sharia-based investment. PRUlink Syariah is designed to meet the society's need for future financial designs in accordance with Islamic principles of sharia. There are two types of product of PRUlink Syariah insurance, namely PRUlink Syariah Investor Account and PRUlink Syariah Assurance Account. Kind of Product in PRUlink Syariah is contract between policy holders using contract of tabarru which is called hibah and the owner of the policy/participant premises sharia insurance company using contract of tijarah called wakalah bin ujrah. In sharia insurance there is a surplus sharing that will be distributed to customers calculated at the end of the calendar year. This can be obtained if there are more funds than tabarru' accounts that have been reduced by claims and debt to the company if any. How is PRUlinksyariah managed in Prudential? The result of the research shows that PRUsyariah premium management in Prudential is separated by two accounts, namely tabarru' account and investment account. The own fund is managed by Eastpring Investment, that is manager company from Asia prudential, while allocation of fund is invested in stocks and obligation which is in accordance with sharia principles contained in the Jakarta Stock Exchange. For the choice of investment in PRUsariah, there are three options of investment, namely ShariaRupiah Equity Fund, Sharia-Rupiah Managed Fund or Sharia-Rupiah fixed Income fund, in accordance with the choice of the next participant. From the investment result the participant agrees to pay tabarru' contribution directly input into tabarru' account. Tabarru' funds are fully owned by participants and used to pay claims participants claim at any time, but if there is tabaaru' funds excess with claims total in one year as of 31 December paid, then tabarru' surplus or that is called surplus will be distributed participants that meet the requirements to get the surplus.
\end{abstract}

Keywords: tabarru' fund management, sharia insurance, prudential life

\section{Pendahuluan}

Kehidupan manusia saat ini sudah sedemikian sarat dengan beragam ancaman dan resiko bahaya, yang dipicu sendiri oleh kelemahannya, kesalahan-kesalahanya, kealpaanya dan ketidakmengertiannya akan masalah metafisis. Manusia tidak dapat mengetahui apa yang akan ia perbuat esok hari, dan manusia pun tidak mengetahui di bumi mana ia meninggal dunia. Manusia setiap waktu dihadapkan dengan sederet bahaya yang mengancam jiwa, harta, 
kehormatan, agama, dan tanah airnya. Manusia juga dihadapkan dengan beragam resiko kecelakaan, mulai dari kecelakaan transportasi udara, kapal hingga angkutan darat dengan beragam jenisnya, ditambah kecelakaan kerja, kebakaran, perampokan, pencurian, sakit hingga kematian. Belum lagi ditambah dengan ancaman mental, seperti kegelisahan mental, perilaku buruk orang-orang yang berinteraksi dengannya, ancaman globalisasi ekonomi, ancaman berbagai perubahan mendadak pada perundang-undangan, dan lain sebagainya. ${ }^{1}$

Upaya untuk mengatasi sifat alamiah yang berwujud sebagai suatu keadaan yang tidak pasti tadi, antara lain dilakukan oleh manusia dengan cara menghindari, atau melimpahkannya kepada pihak-pihak lain di luar dirinya sendiri. Upaya atau usaha manusia untuk mengurangi, menghindarkan risikonya itu sudah lama dilakukan. Usaha itu dimulai sejak permulaan kegiatan ekonomi manusia, yaitu sejak manusia melakukan kegiatan perdagangan yang sederhana. Usaha-usaha manusia untuk mengatasi risiko dengan cara melimpahkannya kepada pihak lain beserta proses pertumbuhannya, dikenal oleh peradaban atau manusia, baik di dunia bagian Timur maupun Tengah pada abad-abad awal sebelum Masehi. ${ }^{2}$

Usaha dan upaya manusia untuk menghindari dan melimpahkan resikonya kepada pihak lain beserta proses pelimpahan sebagai suatu kegiatan itulah yang merupakan embrio atau cikal bakal perasuransian yang dikelola sebagai suatu kegiatan ekonomi yang rumit sampai saat ini. Maka pilihan yang paling tepat terdapat pada institusi yang bernama asuransi. Dalam kegiatan bisnis asuransi, segala sesuatu diarahkan untuk memproteksi keadaan di masa mendatang yang belum pasti terjadi atas sebuah resiko yang berkaitan dengan nilai aktivitas ekonomi seseorang.

Di Indonesia, asuransi bukanlah hal yang tabu lagi, terbukti sekarang pemerintah mulai mewajibkan mempunyai BPJS, yaitu asuransi pemerintah. Dengan seiring berjalannya waktu masyarakat Indonesia yang sebagian besar merupakan warga muslim mulai memilah halal haram dalam pemakaian jasa. Oleh karena itu, akhir-akhir ini banyak sekali bermunculan produk asuransi berbasis syariah di Indonesia. Fenomena ini dimulai dengan munculnya PT. Asuransi Takaful Indonesia.

Setelah Asuransi Takaful dibuka, berbagai perusahaan asuransi menyadari cukup besarnya potensi bisnis asuransi syariah di Indonesia. Hal tersebut kemudian mendorong berbagai perusahaan ramai-ramai masuk bisnis asuransi syariah, di antaranya dilakukan dengan langsung mendirikan perusahaan asuransi syariah penuh maupun membuka divisi atau cabang asuransi syariah. Seperti perusahaan asuransi besar dunia yang turut tertarik masuk dalam bisnis asuransi syariah di Indonesia adalah PT. Prudential Life Assurance (Prudential Indonesia). Asuransi Prudential merupakan salah satu perusahaan asuransi ternama di dunia yang memiliki kantor perusahaan di beberapa belahan dunia termasuk di Indonesia. Perusahaan asuransi Prudential Life Asurance memiliki produk asuransi konvensional maupun syariah.

Pengelolaan dana PT. Prudential Life Assurance dikelola langsung oleh pusat, kantorkantor cabang hanya berperan sebagai perantara bagi nasabah PT. Prudential Life Assurance Pusat. Dalam pengelolaan dana tabarru' yang ada pada PT. Prudential Life Assurance dikelola sendiri oleh perusahaan yang nantinya berfungsi untuk membantu nasabah yang

\footnotetext{
${ }^{1}$ Husain Syabatah, Asuransi Dalam Perspektif Syariah (Jakarta: Sinar Grafika Offset, 2006), 1.

${ }^{2}$ Ibid., 7.
} 
terkena musibah. Sehingga PT. Prudential life Asurance dapat meningkatkan keuntungan bagi perusahan sendiri maupun nasabah (pemegang polis).

\section{Sejarah Asuransi PT. Prudential Life Assurance}

PT. Prudential Life Assurance didirikan tahun 1995 dan merupakan bagian dari Prudential Plc Group, jasa keuangan berbasis di London Inggris yang memiliki pengalaman lebih dari 160 tahun. Prudential Plc merupakan jasa keuangan terkemuka asal Inggris yang berdiri sejak tahun 1948. Di asia Prudential Indonesia menginduk pada kantor regional Prudential Corporation Asia (PCA) yang berkedudukan di Hongkong. Dengan menggabungkan pengalaman internasional Prudential di bidang asuransi jiwa dengan pengetahuan atau bisnis lokal, Prudential Indonesia memiliki komitmen untuk terus mengembangkan bisnisnya di Indonesia. ${ }^{3}$ Grup Prudential memiliki posisi yang kuat pada tiga pasar terbesar dan paling menguntungkan di dunia, yaitu Inggris Raya, Eropa, Amerika Serikat dan Asia. Pada tiga pasar ini kekayaan global yang terus meningkat dan demografi yang dinamis memunculkan permintaan besar untuk produk proteksi jangka panjang dengan investasi. $^{4}$

1 September 2007, Prudential Indonesia meluncurkan produk unit link berbasis syariah, yaitu PRUsyariah atau PRUlink Syariah sebagai produk asuransinya. Sejak itu Prudential Indonesia dikenal sebagai perusahaan asuransi jiwa pelopor untuk produk unit link (asuransi yang dikaitkan dengan investasi) berbasis syariah di Indonesia, dan pada tahun 2010 di Kota Kudus akhirnya didirikan. ${ }^{5}$

Sedangkan dana Investasi PRUlink Syariah, Prudential Indonesia dipercayakan pada Eastpring Invesment yang sebelumya dikenal dengan nama Prudential Fund Management Berhad (PFMB) yang berada di Malaysia dan berkantor cabang di Jakarta untuk di Indonesia. Eastpring Invesmen merupakan bagian dari Prudential Asia dan salah satu pengelola dana terbesar di Asia. Per 31 Desember 2013, Eastpring Invesment mengelola dana sebesar 58,1 miliar dollar atau kurang lebih (793 triliun rupiah). Dana PRUlink Syariah tersebut dikelola dan diinvestasikan di saham-saham perusahan-perusahaan besar yang terbukti menghasilkan yang tidak memilki unsur haram, atau riba dan pada prinsip-prinsip Syariah. ${ }^{6}$

\section{Pengertian Asuransi PT. Prudential Life Assurance}

Asuransi syariah (ta'mix, takaful atau tadkmun) adalah usaha saling melindungi dan tolong menolong di antara sejumlah orang melalui investasi dalam bentuk aset dan atau dana tabarru' yang memberikan pola pengembalian untuk menghadapi resiko tertentu melalui akad yang sesuai dengan syariah. ${ }^{7}$

PRUlink Syariah adalah sebuah produk asuransi yang dikaitkan dengan investasi berbasis syariah. PRUlink Syariah dirancang untuk memenuhi kebutuhan masyarakat akan rancangan keuanga masa depan yang sesuai dengan prinsip prinsip syariah.

\footnotetext{
${ }^{3}$ PT. Prudential Life Assurance, "Prufast Start” (Jakarta: PT. Prudential Life Assurance, 2013), 11.

${ }^{4}$ Ibid., 11.

${ }^{5}$ Ibid., 13.

${ }^{6}$ PT. Prudential Life Assurance, "Prufast Start", 11.

${ }^{7}$ Fatwa Dewan Syariah Nasional Majelis Ulama Indonesia No: 21/DSN-MUI/X/2001.
} 


\section{Produk Asuransi}

Ada dua jenis produk asuransi PRUsyariah yang ditawarkan di PT. Prudential Life Assurance, yaitu:

1. PRUlinkSyariah Investor Account (PIA Syariah)

PRUlink syariah investor account (PIA Syariah) merupakan produk asuransi syariah Prudential dengan pembayaran kontribusi tunggal sekaligus menawarkan berbagai pilihan dana investasi syariah dan proteksi asuransi. Produk ini memberikan perlindungan yang komprehensif terhadap risiko kematian atau risiko menderita cacat total dan tetap. Dalam program PIA Syariah ini terbuka bagi umum, dengan maksimal usia 70 tahun dan akhir manfaat sampai dengan peserta berusia 99 tahun dan minimal kontribusi adalah Rp. 12.000.000, adapun maksimal tidak terbatas. Banyak manfaat yang diperoleh dalam produk ini, seperti untuk pendidikan anak di masa yang akan datang, sebagai persiapan dini untuk warisan bagi anak-anak, untuk biaya pernikahan anak, dan masih banyak manfaat yang akan diperoleh.

2. PRUlink Syariah Assurance Account (PAA Syariah)

PRUlink Syariah Assurance Account (PAA Syariah) merupakan produk asuransi syariah Prudential dengan kontribusi reguler yang menawarkan berbagai pilihan dana investasi yang sesuai dengan prinsip-prinsip syariah dan proteksi asuransi. Dalam program PAA Syariah ini terbuka bagi umum, dengan maksimal usia 65 tahun dan akhir manfaat sampai dengan akhir manfaat. Cara pembayaran sesuai dengan kebutuhan nasabah, seperti tahunan, setengah tahunan, kwartalan dan bulanan. ${ }^{8}$

Sedangkan manfaat-manfaat yang terdapat pada produk PRUlink Syariah Assurance Account adalah sebagai berikut:

a. Manfaat kematian.

b. Manfaat cacat total dan tetap.

c. Dapat menambahkan nilai uang pertanggungan setiap saat.

d. Dapat melakukan penambahan kontribusi setiap saat.

e. Dapat menentukan sendiri besarnya komposisi dari nilai proteksi dan nilai investasi.

f. Dapat melakukan pengalihan dana.

g. Serta pilihan manfaat 15 asuransi tambahan (riders) yang beragam, meliputi:

1) PRUcrisis cover syariah 34

Memberikan uang pertanggungan PRUcrisis cover syariah 34 apabila peserta utama menderita dan memenuhi kriteria salah satu dari 34 kondisi kritis.

2) PRUcrisis cover benefit syariah 34

Memberikan uang pertanggungan PRUcrisis cover benefit syariah 34 apabila peserta utama menderita dan memenuhi kriteria salah satu dari 34 kondisi kritis atau meninggal dunia tanpa mengurangi uang pertanggungan dasar.

3) PRUaccident death syariah

Memberikan manfaat tambahan apabila peserta utama meninggal dunia akibat kecelakaan.

4) PRUaccident death \& disablement syariah

\footnotetext{
${ }^{8}$ Ibid., 15.
} 
Memberikan manfaat tambahan apabila peserta utama mengalami cacat total dan tetap atau meninggal dunia akibat kecelakaan.

5) PRUmed syariah

Manfaat tambahan yang memberikan santunan harian rawat inap, ICU dan pembedahan kepada peserta utama jika menjalani rawat inap di rumah sakit.

6) PRUhospital and surgical syariah

Manfaat tambahan yang memberikan penggantian seluruh biaya rawat inap, ICU dan pembedahan sesuai dengan manfaat yang diambil, selama peserta utama menjalani perawatan di rumah sakit.

7) PRUwaiver syariah 33

Jika peserta utama menderita dan memenuhi kriteria salah satu dari 33 kondisi kritis, PT. Prudential Life Assurance akan melanjutkan pembayaran kontribusi dasar sampai berakhirnya masa pertanggungan yang dipilih.

8) PRUpayor syariah 33

Jika peserta utama menderita dan memenuhi kriteria salah satu dari 33 kondisi kritis, PT. Prudential Life Assurance akan melanjutkan pembayaran seluruh kontribusi sampai berakhirnya masa pertanggungan yang dipilih.

9) PRUspouse waiver syariah 33

Jika suami/istri dari peserta utama menderita dan memenuhi kriteria salah satu dari 33 kondisi kritis atau mengalami cacat total dan tetap sebelum usia 70 tahun atau meninggal dunia, PT. Prudential Life Assurance akan melanjutkan pembayaran kontribusi dasar sampai berakhirnya masa pertanggungan yang dipilih.

10) PRUspouse payor syariah 33

Jika suami/istri dari peserta utama menderita dan memenuhi kriteria salah satu dari 33 kondisi kritis atau mengalami cacat total dan tetap sebelum usia 70 tahun atau meninggal dunia, PT. Prudential Life Assurance akan melanjutkan pembayaran seluruh kontribusi sampai berakhirnya masa pertanggungan yang dipilih dan PRUsaver.

11) PRUparent payor syariah 33

Jika ayah dan/atau ibu dari peserta utama menderita dan memenuhi kriteria salah satu dari 33 kondisi kritis atau mengalami cacat total dan tetap sebelum usia 70 tahun atau meninggal dunia, PT. Prudential Life Assurance akan melanjutkan pembayaran kontribusi dasar sampai berakhirnya masa pertanggungan yang dipilih.

12) PRUlink term syariah

Manfaat tambahan yang diberikan jika peserta utama meninggal dunia sebelum berakhirnya masa pertanggungan yang dipilih.

13) PRUmultiple crisis cover syariah

Memberikan uang pertanggungan PRUmultiple crisis cover syariah apabila peserta utama menderita salah satu dari 34 kondisi kritis, dengan maksimum sebanyak 3 kondisi kritis dalam kelompok yang berbeda, tanpa mengurangi uang pertanggungan dasar. 
14) PRUcrisis income syariah

Memberikan pembayaran manfaat pendapatan sebesar uang pertanggungan PRUcrisis income syariah sampai berakhirnya masa pertanggungan yang dipilih apabila peserta utama menderita salah satu dari 33 kondisi kritis.

15) PRUearly stage cover syariah

Memberikan perlindungan finansial atas 79 penyakit dan kondisi kritis yang terbagi dalam tiga tahap (awal, menengah, dan lanjut) dan melengkapi perlindungan atas penyakit kritis untuk memastikan anda terlindungi secara menyeluruh. Selain perlindungan terhadap penyakit kritis, PRUearly stage cover syariah juga memberikan manfaat tambahan untuk tiga kondisi kritis, yakni angiosplasti dan penatalaksanaan invasif lainnya untuk penyakit, pembuluh darah jantung, komplikasi akibat diabetes dan kebutaan pada kedua mata. ${ }^{9}$

\section{Akad pada Produk PRUsyariah}

Jenis akad pada produk PRUsyariah adalah:

1. Akad tabarru' yaitu akad antara sesama pemilik polis/peserta yang disebut hibah.

2. Akad tijaæah yaitu akad antara pemilik polis/peserta dengan perusahaan Prudential yang disebut wakatah bi al-ujrah. ${ }^{10}$

Untuk investasi, asuransi PRUsyariah meluncurkan tiga produk investasi syariah berbasis unit link yang tersedia bagi para investor yang ingin menginvestasikan dana ke dalam Prudential syariah ini. Tiga produk investasi syariah Prudential di antaranya yaitu:

1. PRUlink Syariah Rupiah Managed Fund (Investasi seimbang, resiko sedang)

PRUlink Syariah Rupiah Managed Fund memaksimalkan perkembangan dana jangka panjang melalui investasi dengan nilai rupiah pada obligasi syariah dan saham syariah. Alokasi aset ditentukan oleh fund manager dan dapat diubah dari waktu ke waktu. Dana ini cocok bagi investor yang mendambakan penghasilan investasi jangka panjang yang menarik serta bersedia menanggung risiko investasi yang tidak terlalu tinggi atau menengah dan bervariasi.

2. PRUlink Syariah Rupiah Equity Fund (Investasi saham, resiko tinggi)

PRUlink Syariah Rupiah Equity Fund bertujuan memaksimalkan pendapatan jangka menengah dan panjang melalui investasi dalam saham saham syariah dan berkualitas yang tercatat di Bursa Efek Jakarta. Investasi ini cocok untuk investor yang menginginkan penghasilan investasi jangka panjang dengan hasil yang lebih tinggi serta bersedia menanggung resiko investasi yang tinggi.

3. PRUlink Syariah Rupiah Cash and Bond Fund (Investasi deposito dan obligasi, resiko sedang).

PRUlink Syariah Rupiah Cash and Bond Fund adalah dana investasi jangka menengah dan panjang yang bertujuan untuk mendapatkan hasil investasi yang optimal melalui penempatan dana dalam mata uang rupiah melalui instrumen-instrumen pasar uang syariah dan pendapatan tetap syariah seperti obligasi syariah dan instrumen pendapatan tetap syariah lainnya di pasar modal. Investasi ini cocok untuk investor yang

\footnotetext{
${ }^{9}$ PT. Prudential Life Assurance, "Prufast Start", 86-89.

${ }^{10}$ Ibid., 84.
} 
mendambakan penghasilan jangka menengah dan panjang yang stabil serta bersedia menanggung resiko investasi yang tidak terlalu tinggi atau menengah. Produk ini memberikan keleluasaan bagi pemegang polis untuk memilih investasi syariah yang memungkinkan optimalisasi tingkat pengembalian investasinya, sesuai dengan kebutuhan dan profil resiko pemegang polis. ${ }^{11}$

\section{Mekanisme Pengelolahan Dana Tabarnu'}

Dalam prakteknya, asuransi syariah menerapkan prinsip saling kerjasama dan tolong menolong, jadi jika ada keuntungan akan dibagi rata dan jika ada kerugian maka akan dirasakan bersama. Pada hakekatnya słb al-ma batau nasabah yang membayar premi di asuransi memiliki tujuan untuk memiliki rasa aman jika sewaktu-waktu mereka ditimpa musibah yang entah kapan akan terjadi. Dengan membayarkan premi di asuransi maka nasabah percaya kepada perusahaan asuransi syariah terkait untuk dapat mengelola dana tersebut sehingga jika sewaktu-waktu mereka tertimpa musibah maka mereka dapat terbantu dari perusahaan asuransi syariah. Untuk lebih dapat menjelaskan mekanisme pengelolaan dana tabarru' pada produk PRUsyariah, berikut akan dijelaskan bagaiman mekanisme pengelolaan dana tabarru pada PRUsyariah prudential.

Pengelolaan premi PRUsyariah di Prudential dipisahkan dua rekening, yaitu rekening tabarru' dan rekening investasi, untuk pengelolaan dana sendiri dikelola oleh Eastpring Investmen, yaitu perusahaan manajer dari Prudential Asia, sedangkan alokasi dana diinvestasikan di saham-saham dan obligasi syariah yang sesuai dengan prinsip syariah yang terdapat di Bursa Efek Jakarta. Untuk pilihan investasi di PRUsariah terdapat tiga pilihan investasi, yaitu Rupiah Equity Fund Syariah, Rupiah Managed Fund Syariah ataupun Rupiah Fixed Income Fund Syaria, sesuai dengan pilihan peserta. Selanjutnya, dari hasil investasi tersebut peserta sepakat membayar iuran tabarru' yang langsung dimasukkan dalam rekening tabarru'. Dana tabarru' sendiri sepenuhnya dimiliki peserta dan dipergunakan untuk pembayaran klaim sewaktu-waktu peserta mengajukan klaim, tetapi apabila terjadi kelebihan dana tabaru' dengan total klaim dalam satu tahun per 31 Desember yang harus dibayarkan, maka kelebihan dana tabarru' atau yang disebut surplus ini akan dibagikan ke peserta yang memenuhi persyaratan untuk mendapatkan surplus tersebut. ${ }^{14}$

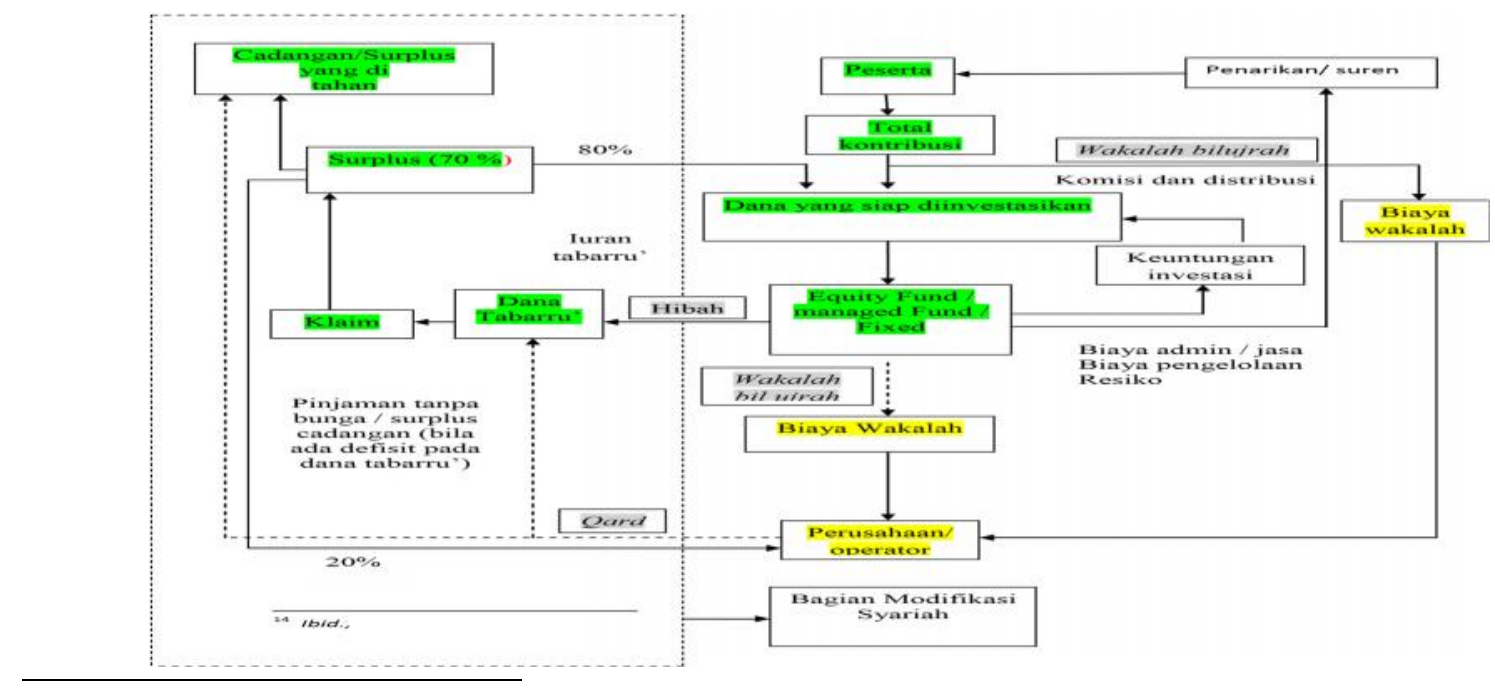

${ }^{11}$ Ibid., 88 . 
Adapun penjelasan dari bagan di atas sebagai berikut:

1. Peserta membayar kontribusi. Dari total kontribusi tersebut, sebagian langsung diinvestasikan, dan sebagian lagi dipergunakan untuk membayar biaya komisi dan distribusi yang merupakan bagian dari biaya wakalah yang dikenakan oleh operator atau perusahaan asuransi syariah. Jenis akad yang digunakan adalah akad wakatah bi al-ujrah.

2. Dana-dana dari pembayaran kontribusi peserta tersebut diinvestasikan melalui pembelian unit-unit pada dana-dana investasi yang tersedia, yaitu Rupiah Equity Fund Syariah, Rupiah Managed Fund Syariah, ataupun Rupiah Fixed Income Fund Syariah sesuai pilihan peserta.

3. Dari hasil investasi yang diperoleh, peserta sepakat untuk membayar iuran tabarru' bulanan yang langsung dimasukkan ke dalam dana tabarru', dan yang akan digunakan adalah akad hibah.

4. Dana tabarru' dimiliki sepenuhnya oleh peserta dan dipergunakan untuk membayarkan klaim jika ada peserta yang mengajukannya. Tetapi bila tidak terjadi klaim atau terdapat kelebihan antara dana tabarru' dengan total klaim yang harus dibayarkan, maka kelebihan atau yang disebut surplus ini akan dibagikan ke peserta yang memenuhi persyaratan untuk memperoleh surplus sharing. $30 \%$ dari surplus sharing disimpan terlebih dahulu ke dalam dana cadangan, sementara yang $70 \%$ sisanya akan dibagikan sebesar $80 \%$ ke peserta dan $20 \%$ ke perusahaan. Surplus sharing yang diperoleh peserta akan dipergunakan untuk membeli unit investasi kembali sehingga akan menambah jumlah unit yang dimiliki peserta.

5. Namun apabila dana tabarru' tidak mencukupi untuk membayarkan klaim, maka peserta bisa meminjam dana kepada operator tanpa dikenakan bunga. Pinjaman ini diperoleh dari dana yang tersedia pada dana cadangan hasil pembagian dari $30 \%$ surplus sharing. Akad yang digunakan untuk pinjaman ini adalah akad qard\}

Surplus sharing adalah dana yang akan diberikan kepada pemegang polis bila terdapat kelebihan dana dari rekening tabarru', termasuk juga bila ada pendapatan lain setelah dikurangi klaim dan hutang kepada perusahaan.

a. Ketentuan surplus sharing

Ketentuan-ketentuan surplus sharing adalah sebagai berikut:

1) Dihitung pada akhir tahun kalender (1 Januari s/d 31 Desember setiap tahun).

2) $30 \%$ dari surplus sharing akan ditahan dalam rekening tabarru', dan sisa $70 \%$ dari surplus sharing akan dibagikan kepada peserta dan perusahaan, dengan pembagian $80 \%$ dibagikan ke pemegang polis/peserta, dan $20 \%$ merupakan hak perusahaan sebagai bagian dari keuntungan.

3) Surplus sharing dibayarkan setiap tanggal 30 April setiap tahun baik ke perusahaan maupun ke peserta.

b. Persyaratan peserta penerima surplus sharing

Peserta yang berhak menerima surplus sharing harus memenuhi persyaratan atau ketentuan sebagai berikut:

1) Tidak terjadi klaim sampai dengan tanggal 30 Desember.

2) Peserta telah memiliki polis sekurang-kurangya 1 bulan per tanggal 31 Desember. 
3) Polis inforce dan iuran tabarru' telah dibayarkan per 31 desember.

4) Polis masih inforce sampai dengan surplus dibagikan.

c. Persyaratan pembagian surplus sharing

1) Surplus sharing dibagikan secara proposional kepada peserta yang waktu kepesertaannya belum mencapai 1 tahun pada saat surplus dihitung (tergantung dari jumlah bulan dan jumlah biaya tabarru'nya).

2) Bila pemegang polis/peserta yang telah dihitung pembagian surplusnya pada akhir 31 Desember tetapi tidak lagi memenuhi persyaratan untuk menerima surplus pada 30 April, misalnya karena pemegang polis melakukan surrender atau memutuskan kontrak polisnya pada jangka waktu tersebut, maka jatah surplusnya akan dikembalikan lagi ke dalam rekening tabarru'. Ini juga yang disebut sebagai "pendapatan lain" pada surplus sharing.

3) Surplus sharing yang telah dibagikan akan dipergunakan untuk membeli unit dengan menggunakan perhitungan harga yang akan datang.

6. Di sini kita lihat bahwa peran perusahaan adalah hanya sebagai operator atau pelaksanan administrasi saja. Oleh karena itu, perusahaan menarik biaya administrasi bulanan, biaya pengelolaan resiko dan pengelolaan dana tabarru', serta biaya investasi. Akad yang digunakan untuk pembayaran biaya-biaya tersebut adalah menggunakan akad wakateh bi al-ujrah, dan biaya-biaya ini disebut juga sebagai biaya wakalah. ${ }^{12}$

7. Adapun produk PRUsyariah di Prudential adalah PRUlink Syariah Assurance Account (PAA), PRUlink Syariah Assurance Account (PAA Syariah) merupakan produk asuransi syariah Prudential dengan kontribusi reguler yang menawarkan berbagai pilihan dana investasi yang sesuai dengan prinsip-prinsip syariah dan proteksi asuransi. Dalam program PAA Syariah ini terbuka bagi umum, dengan maksimal usia 65 tahun dan akhir manfaat sampai dengan akhir manfaat. Cara pembayaran sesuai dengan kebutuhan nasabah, seperti tahunan, setengah tahunan, kwartalan dan bulanan.

\section{Kesimpulan}

PRUlink Syariah adalah sebuah produk asuransi yang dikaitkan dengan investasi berbasis syariah. PRUlink Syariah dirancang untuk memenuhi kebutuhan masyarakat akan rancangan keuanga masa depan yang sesuai dengan prinsip prinsip syariah Islam. Prudential Indonesia memiliki dua jenis produk asuransi PRUlink Syariah, yaitu PRUlink Syariah Investor Account dan PRUlink Syariah Assurance Account. Jenis akad pada produk PRUlink Syariah ada dua. Pertama, untuk akad antara sesama pemilik polis/peserta menggunakan akad tabarru' yang disebut hibah. Kedua, untuk akad antara pemilik polis/peserta dengan perusahaan asuransi syariah menggunakan akad tija $a h$ yang disebut wakałah bi al-ujrah.

Pengelolaan premi PRUsyariah di Prudential dipisahkan dua rekening, yaitu rekening tabarru' dan rekening investasi. Untuk pengelolaan dana sendiri dikelola oleh Eastpring Invesment, yaitu perusahaan manajer dari Prudential Asia, sedangkan alokasi dana diinvestasikan di saham-saham dan obligasi syariah yang sesuai dengan prisip syariah yang terdapat di Bursa Efek Jakarta. Untuk pilihan investasi di PRUsyariah terdapat tiga pilihan investasi, yaitu Rupiah Equity Fund Syariah, Rupiah Managed Fund Syariah ataupun Rupiah

${ }^{12}$ Ibid., 177. 
Fixed Income Fund Syaria, sesuai dengan pilihan peserta selanjutnya, dari hasil investasi tersebut peserta sepakat membayar iuran tabarru' yang langsung dimasukan dalam rekening tabarru'.

Dana tabarru' sendiri sepenuhnya dimiliki peserta dan dipergunakan untuk pembayaran klaim sewaktu-waktu peserta mengajukan klaim, tetapi apabila terjadi kelebihan dana tabarru' dengan total klaim dalam satu tahun per 31 desember yang harus dibayarkan, maka kelebihan dana tabarru' atau yang disebut surplus ini akan di bagikan kepesrta yang memenuhi persyaratan untuk mendapatkan surplus tersebut.

\section{Daftar Rujukan}

Syabatah, Husain. Asuransi Dalam Perspektif Syariah. Jakarta: Sinar Grafika Offset, 2006. PT. Prudential Life Assurance. PRUfast start. Jakarta: PT. Prudential Life Assurance, 2013. PT. Prudential Life Assurance. PRUlink. Jakarta: PT. Prudential Life Assurance, 2013. www.DSNMUI.co.id www.prudential.co.id www.pru.co.uk www.prudentialagentportal.co.id http: //mekanisme_pengelolahan_dana_tabarru'. http: //observasi_danatabarru'_prudential_indonesia. 